\title{
Path Coefficient Analysis of Early Maturing Maize (Zea Mays) Inbred Lines in Central Rift Valley of Ethiopia
}

\author{
Mieso Keweti Shengu \\ Plant Science Department, College of Agriculture and Natural Resources, Dilla University, Dilla, Ethiopia
}

Email address:

kewetimieso@yahoo.com

To cite this article:

Mieso Keweti Shengu. Path Coefficient Analysis of Early Maturing Maize (Zea Mays) Inbred Lines in Central Rift Valley of Ethiopia. Plant. Vol. 5, No. 3, 2017, pp. 47-50. doi: 10.11648/j.plant.20170503.11

Received: May 13, 2017; Accepted: June 21, 2017; Published: August 22, 2017

\begin{abstract}
This work was executed to work out direct and indirect effects of yield related traits on grain yield by path coefficient analysis in early maturing maize inbred lines. Hence, fifteen inbred lines were crossed in a diallel mating system. Two standard checks along with one candidate variety and hybrids were evaluated in Alpha Lattice Design with two replications at Melkassa Research Center. Path-coefficient analysis indicated that most traits; exerted positive direct effects on grain yield both at genotypic and phenotypic levels on grain yield. This suggests that grain yield could simultaneously be improved by selecting for these traits. In general, this study identified inbred lines and hybrid associations that had desirable expression of important traits. This will be useful for the selection of high yielding and early maturing hybrids for the location.
\end{abstract}

Keywords: Path-Coefficient, Maize Inbred Lines, Early Maturing, Melkassa

\section{Introduction}

Maize is one of the most important crops in the world. It is used as a human food, livestock feed, different alcoholic and none alcohol drinks production, building material, and as fuel. It is also used to produce medicinal products such as glucose as well as an ornamental plant [1].

In Ethiopia, during the 2015 cropping season, 2,110,209.61 hectares of land was covered with maize with an estimated production of about 72,349,551.02 [2]. However, the national average yields 2.9 tons/ha CSA [2] is still far below the world average 6.1 tons/ha, [3].

Such low grain yield of maize is attributable to lack of improved varieties for different agro-ecological regions, diseases and insect pests, moisture stress, poor cultural practices, excessive plant height and low soil fertility [1].

One of the important strategies plant breeders adopted to overcome the problem of getting a better yield is to select germplasm that used to identify high yielding genotypes that may give a reasonable yield on different soil and environmental conditions [4].

The reason for selecting early maturing maize inbred lines is that no work has been done for understanding and describing the nature and extent of genotypic and phenotypic association as well as correlation and association between yield and yield components of early maturing maize inbred lines in Central Rift valley of Ethiopia so far. Information on association of locally available and introduced early maturing elite maize inbred lines is very important for future development strategies for drought stress areas of Ethiopia. Therefore, the current study is designed to estimate correlation among yield and yield related traits; and to work out direct and indirect effects of these traits on grain yield by path coefficient analysis in drought stress areas.

\section{Materials and Methods}

\subsection{Treatments and Experimental Design}

The experimental materials used for the current experiment consisted of a total of 108 entries which comprised of 105 single crosses developed from $15 \times 15$ diallel crosses (excluding the reciprocal crosses and parents) inbred lines, along with two standard checks; namely, Melkassa-2; BH-543 and one elite variety Melkassa hybrid-130. The experiment was laid out in 9 x 12 alphalattice designs Patterson and Williams, [5] with two 
replications at Melkassa Research Center during 2011, cropping season. Fifteen inbred lines were crossed in a diallel fashion and 105 different crosses along with two checks and one elite variety were included for association studies.

The parental lines were originally obtained from CIMMYT and selected for per se performance across drought stressed environments in Central Rift Valley of Ethiopia. The checks were excluded from the genetic analysis. The net plot size was $4.25 \mathrm{~m} \times 0.75 \mathrm{~m}=3.2 \mathrm{~m}^{2}$. Planting was done by hand on June 27, 2011. Two seeds were sown per hill which later thinned to one plant per hill after seedlings established well to get a total plant population of 53,333 per ha. $100 \mathrm{DAP}$ and 50 Urea kg per hectare were applied uniformly for each location. DAP was applied at planting while whole Urea was applied at knee height stage of the crop. All other recommended crop management practices were applied uniformly.

\subsection{Data Collected}

Data were recorded on plot and single plant basis for the following parameters to represent their respective characters.

Data Collected on plot bases: days to emergence, days to anthesis, days to silking, anthesis-silking interval, ears per plant, days to maturity and thousand kernel weights.

Data recorded using random sample of 5 plants or ears from each plot. plant height, ear height, number of ears per plant, ear length, ear diameter, number of kernel rows per row, number of kernels per row, number of kernels per.

\subsection{Data Analysis}

The data were analyzed for combining ability using Griffing, [6].

\section{Results and Discussion}

\subsection{Phenotypic Path-Coefficient Analysis}

The phenotypic direct and indirect effects of yield-related traits on grain yield were presented in (Table 1). Days to anthesis, anthesis silking interval, plant height, ear height, ear per plant, days to maturity, ear length, ear diameter, number of kernels per ear and thousand kernel weight exerted positive direct effects on grain yield. Plant height, ear height, ear per plant, ear length, ear diameter, number of kernels per row, number of rows per ear and number of kernels per ear showed positive and significant correlation with grain yield.

Among these traits, plant height, ear height, ear per plant, ear length, ear diameter, number of kernels per row exerted favorable direct effect on grain yield, indicating; that improvement of these traits would contribute to increase yield keeping other traits constant. Similarly, Hadji Tuna [7] found positive direct effects of ear height, and ear length, ear diameter on grain yield and also positive and significant correlations of these traits on grain yield. Bullo Neda [8] also reported positive and direct effects of plant height and ear diameter. In contrast to the current study, he reported favorable direct effect of number of kernels per plant and thousand kernels weight on grain yield.

Even though days to anthesis, days to silking and anthesis silking interval associated negatively and significantly with grain yield, these traits exerted positive direct effects on grain yield. The negative associations of days to anthesis, days to silking and anthesis silking interval with grain yield was attributed to the negative indirect effects of these traits through plant height, ear height, ear per plant height, ear height, ear per plant, ear length, ear diameter and number of kernels per ear. Under these circumstances, a restricted simultaneous selection model is to be followed, i.e. restrictions are to be imposed to nullify the undesirable indirect effects through the above traits [9].

Table 1. Phenotypic path coefficient analysis of the direct (bold) and indirect effects of 15 traits on grain yield in diallel hybrids of elite early maturing inbred lines.

\begin{tabular}{|c|c|c|c|c|c|c|c|c|c|c|c|c|c|c|}
\hline Variable & DA & DS & ASI & PH & EH & EPP & DM & EL & ED & KPR & RPE & KPE & TKW & rp \\
\hline DA & 2.199 & -2.326 & -0.056 & -0.024 & 0.025 & -0.032 & 0.006 & -0.008 & -0.005 & 0.003 & -0.034 & 0.031 & -0.012 & $-0.19 * *$ \\
\hline DS & 2.170 & -2.357 & -0.012 & -0.024 & 0.017 & -0.032 & 0.006 & -0.008 & -0.005 & 0.002 & -0.036 & 0.035 & -0.013 & $-0.21 * *$ \\
\hline ASI & -0.449 & 0.103 & 0.277 & 0.000 & -0.054 & 0.004 & -0.001 & 0.004 & 0.002 & -0.009 & -0.006 & 0.019 & 0.000 & $-0.11 * *$ \\
\hline PH & -0.618 & 0.678 & -0.001 & 0.084 & 0.191 & 0.052 & -0.002 & 0.021 & 0.017 & -0.065 & -0.011 & 0.092 & 0.008 & $0.47 * *$ \\
\hline EH & 0.158 & -0.113 & -0.043 & 0.046 & 0.349 & -0.007 & 0.000 & 0.001 & -0.010 & -0.010 & -0.005 & 0.017 & 0.007 & $0.37 * *$ \\
\hline EPP & -0.288 & 0.308 & 0.005 & 0.018 & -0.009 & 0.246 & 0.013 & 0.000 & 0.002 & 0.007 & -0.014 & 0.006 & -0.004 & $0.33 * *$ \\
\hline DM & 0.992 & -1.058 & -0.019 & -0.013 & 0.011 & -0.025 & 0.013 & 0.028 & 0.086 & -0.074 & -0.096 & 0.207 & 0.004 & $-0.07 \mathrm{~ns}$ \\
\hline EL & -0.281 & 0.284 & 0.016 & 0.028 & 0.007 & 0.029 & 0.000 & 0.063 & 0.024 & -0.262 & -0.015 & 0.342 & 0.001 & $0.28 * *$ \\
\hline ED & -0.123 & 0.126 & 0.007 & 0.017 & -0.039 & 0.017 & 0.000 & 0.028 & 0.086 & -0.015 & -0.250 & 0.310 & -0.007 & $0.21 * *$ \\
\hline KPR & -0.027 & 0.017 & 0.009 & 0.021 & 0.013 & 0.020 & 0.000 & 0.038 & 0.024 & -0.262 & -0.172 & 0.451 & -0.004 & $0.22 * *$ \\
\hline RPE & 0.299 & -0.336 & 0.007 & 0.004 & 0.007 & -0.005 & 0.001 & -0.001 & 0.033 & -0.015 & -0.250 & -0.035 & -0.007 & $0.06 \mathrm{~ns}$ \\
\hline KPE & 0.152 & -0.183 & 0.012 & 0.017 & 0.013 & 0.010 & 0.000 & 0.026 & 0.039 & -0.199 & -0.172 & 0.451 & -0.004 & $0.20^{* *}$ \\
\hline TKW & -0.530 & 0.581 & -0.001 & 0.013 & 0.047 & -0.004 & -0.001 & 0.005 & 0.006 & -0.004 & 0.034 & -0.035 & 0.051 & $0.14 * *$ \\
\hline
\end{tabular}

$\mathrm{GY}=$ grain yield, $\mathrm{DA}=$ days to maturity, $\mathrm{DS}=$ days to silking, $\mathrm{ASI}=$ anthesis silking interval, $\mathrm{PH}=$ plant height, $\mathrm{EH}=\mathrm{ear}$ height, $\mathrm{EPP}=\mathrm{ear}$ per plant, $\mathrm{DM}=\mathrm{days}$ to maturity, $\mathrm{EL}=$ ear length, $\mathrm{ED}=$ ear diameter, $\mathrm{KPR}=$ number of kernels per row, $\mathrm{RPE}=$ number of rows per ear, $\mathrm{KPE}=$ number of kernels per ear and TKW=thousand kernel weights. 


\subsection{Genotypic Path-Coefficient Analysis}

The genotypic direct and indirect effects of yield-related traits on grain yield were presented in (Table 2). Plant height and ear length exerted positive direct effects on grain yield and also positive correlation with grain yield due to their positive indirect effects through ear height and number of kernels per row. In line with the current study, Djordjevic and Ivanovic, [10] reported that plant height exerted positive direct effect and positive association with grain yield. Hadji Tuna [7] also found positive direct effects and positive associations of plant height and ear length with grain yield, which agrees with result of the current study. Ear per plant and ear diameter also exerted positive direct effects on grain yield. Number of kernels per row and number of rows per ear showed negative direct effects but exhibited positive genotypic correlation with grain yield due to its positive indirect effect through number of kernels per row. According to Singh and Kakar [11], whenever a trait had positive association and high positive indirect effects but negative direct effect, emphasis should be given to the indirect effects and indirect causal factors are to be considered simultaneously for selection in this case.

On the other hand, other hand ear height, ear per plant, ear length, ear diameter and number of kernels per ear exerted positive direct effect and also had positive association with grain yield. These traits could be used as a reliable indicator in indirect selection for higher grain yield since their direct effect and association with grain yield were positive. Djordjevic and Ivanovic, [10] reported similar results on the strong association of ear height with grain yield.
Number of kernels per row exerted the highest positive direct effects and also exhibited positive correlation with grain yield, implying that this trait can be used as a good indicator of increased grain yield in indirect selection. Ear height exerted positive indirect effects on grain yield through number of kernels per row. Similar to this finding, Hadji Tuna [7] found ear height exerting highest negative direct effect, even though it exhibited positive correlation with grain yield due to its positive indirect effects through number of kernels per ear, ear diameter and ear per plant.

Ear diameter exerted positive direct effects on grain yield and correlated positively with grain yield and also exhibited positive indirect effects through ear per plant, ear length and number of kernels per ear. Since their direct effects on yield were small, the indirect effects seem to be the cause of strong correlation.

Thus, indirect causal factors are to be considered simultaneously for selection in both cases as reported by [11]. Ear per plant exerted the second largest positive direct effects on grain yield, after number of kernels per ear and also exhibited positive correlation with grain yield. It also exerted positive indirect effects through number of kernels per ear.

The genotypic direct effect of number of kernels per ear (0.38) and ear per plant (0.31) were high and also their positive genotypic and phenotypic correlations with grain yield were significant $\left(\mathrm{rg}=0.35^{* *}\right.$ and $0.47^{* *}$, and $\mathrm{rp}=0.20^{* *}$ and $0.33^{* *}$, respectively) indicating that part of variability observed in grain yield could be explained by those two traits.

Table 2. Genotypic path analysis of the direct (bold) and indirect effects of 15 traits on grain yield in diallel crosses of elite early maturing maize inbred lines.

\begin{tabular}{|c|c|c|c|c|c|c|c|c|c|c|c|c|c|c|}
\hline Variable & DA & DS & ASI & PH & EH & EPP & DM & EL & ED & KPR & RPE & KPE & TKW & $\mathrm{rg}$ \\
\hline DA & -0.843 & 0.279 & 0.061 & 0.307 & 0.250 & 0.054 & 0.161 & 0.156 & 0.103 & 0.151 & 0.079 & 0.157 & 0.025 & $0.31 * *$ \\
\hline DS & 0.307 & 0.684 & 0.026 & 0.301 & 0.240 & 0.048 & 155 & 0.151 & 0.096 & 0.154 & 0.079 & 0.160 & 0.025 & $0.28 * *$ \\
\hline ASI & -0.075 & -0.029 & -0.160 & -0.097 & -0.119 & -0.048 & -0.073 & -0.062 & -0.072 & -0.007 & -0.007 & -0.007 & -0.006 & $-0.25 * *$ \\
\hline PH & 0.170 & 0.151 & 0.044 & 0.078 & 0.353 & & 34 & 0.247 & 0.113 & 173 & 0.046 & 0.135 & 0.012 & $0.56^{* *}$ \\
\hline EH & 174 & 0.152 & 0.0 & 0.445 & 0.133 & & & & 51 & 110 & 0.014 & 0.066 & 0.008 & $0.45 * *$ \\
\hline EPP & 035 & 0.029 & 0.026 & 0.129 & 0.072 & 0.309 & 0.015 & 0.039 & 0.023 & 0.049 & 0.015 & 0.037 & 0.018 & $0.47 * *$ \\
\hline DM & 137 & 0.120 & 0.050 & 0.206 & 0.179 & 0.020 & 0.129 & 0.156 & 0.079 & 0.055 & 0.006 & 0.034 & -0.001 & $0.37 * *$ \\
\hline EL & 0 & 0.085 & 31 & 0.278 & 0.160 & 0.037 & 0.114 & 0.163 & 0.176 & 0.176 & 0.013 & 0.105 & -0.007 & $0.50 * *$ \\
\hline ED & 0.074 & 0.062 & 0.042 & 0.147 & 0.053 & 0.025 & 0.066 & 0.203 & 0.181 & 0.106 & 0.120 & 0.186 & -0.001 & $0.43 * *$ \\
\hline KPR & 129 & 0.120 & 0.005 & 0.269 & 0.135 & 0.063 & 0.056 & 0.243 & 0.127 & -0.250 & 0.069 & 0.295 & 0.029 & $0.22 * *$ \\
\hline RPE & 110 & .101 & 0.008 & 0.115 & 0.028 & 0.031 & 0.010 & 0.028 & 0.233 & 0.113 & -0.214 & 0.295 & 0.029 & $0.22 *$ \\
\hline KPE & 0.141 & 0.130 & 0.005 & 0.219 & 0.086 & 0.050 & 0.036 & 0.152 & 0.234 & 0.273 & 0.190 & 0.375 & 0.031 & $0.35^{* *}$ \\
\hline TKW & -0.070 & -0.063 & -0.013 & -0.062 & -0.033 & -0.074 & 0.002 & 0.030 & 0.004 & -0.067 & -0.059 & -0.098 & -0.062 & $-0.11 n s$ \\
\hline
\end{tabular}

$\mathrm{GY}=$ grain yield, $\mathrm{DA}=$ days to maturity, $\mathrm{DS}=$ days to silking, $\mathrm{ASI}=$ anthesis silking interval, $\mathrm{PH}=$ plant height, $\mathrm{EH}=$ ear height, $\mathrm{EPP}=\mathrm{ear}$ per plant, $\mathrm{DM}=\mathrm{days}$ to maturity, $\mathrm{EL}=$ ear length, $\mathrm{ED}=$ ear diameter, $\mathrm{KPR}=$ number of kernels per row, $\mathrm{RPE}=$ number of rows per ear, $\mathrm{KPE}=$ number of kernels per ear and TKW=thousand kernel weights.

\section{Conclusion}

The path coefficient analysis at phenotypic level showed that plant height, ear height, ear per plant, ear length, ear diameter, number of kernels per ear and thousand kernel weights exerted positive direct effects on grain yield. As these traits influenced grain yield favorably, selection for those traits will lead to the improvement of grain yield. At genotypic level plant height, ear height, ear per plant, days to maturity, ear length, ear diameter and number of rows per ear exerted positive direct effects, indicating that possibility to increase grain yield through improving these traits. Thus, improving these traits leads to improvement of grain yield indirectly.

Generally, the results of the current study identified that 
inbred lines with positive direct effects on grain yield both at phenotypic and genotypic levels. Hence, the information from this study may possibly be useful for researchers who would like to develop high yielding varieties of maize by identifying its direct and indirect effects on grain yield.

\section{Acknowledgements}

The author extends his gratitude to Melkassa Agricultural Research Center and Dagne Wegary for financial support.

\section{References}

[1] Abera Debelo, 1982. Dry matter production and distribution by two maize (Zea mays. L) hybrids and their parental lines. MSc. Thesis submitted to School of Graduate Studies, Addis Ababa University.

[2] Central Statistical Authority (CSA). 2015/16. Crop production sample survey reports on the area \& production forecast for major crops (private peasant holdings Meher season). The FDRRE Statistical Bulletins (September 11-October 25, 2010). PP. 136. Vol. 7. Addis Ababa, Ethiopia.

[3] FAOSTAT. 2015/16. Food and Agriculture Organization Statistical Database: http// faostat.fao.org.

[4] Kaur, G., P. Bansal, B. Kaur and S. Banga, 2007. Genetic diversity and its association with heterosis in Brassica rapa. Proceedings, The 12 international rapeseeds congress, Science. press USAInc., 1: 144-146.

[5] Patterson HD, Williams ER, A new class resolvable incomplete block designs. Biometrika, 1976, 63, 83-92.

[6] Griffing, B., 1956. Concept of general and specific combining ability in relation to diallel crossing systems. Australian. J. Biol. Sci. 9: 463-493.

[7] Hadji Tuna, 2004. Combining Ability Analysis for yield and yield related traits in quality Protein maize (QPM) inbred lines. M. Sc. Thesis submitted to School of Graduate studies, Alemaya University.

[8] Bullo Neda, 2010. Combining ability analysis for grain yield, yield components and some agronomic traits in quality protein maize (QPM) inbred lines at Mechara, Ethiopia.

[9] Vasal, S. K. G. Srinivasan, F. Gonzalez, C. D. L. Beck and J. Crossa, 1993a. Heterosis and combining ability of CIMMYT's quality protein maize germplasm: II. Subtropical. Crop Sci. 33 (1-3): 51-57.

[10] Djordjevic, S. J. and R. M. Ivanovic, 1996. Genetic analysis for stalk lodging resistance in narrow-base maize synthetic population ZP 514. Crop Science. 36: 909-913.

[11] Singh, R. K. and S. N. Kakar, 1977. Cotton on individual trait means during index selection. Proceeding of third congr. SABRAO (Canberra). 3: 22-25. 